\title{
Exploratory Research Design in Management Sciences: An X-Ray of Literature
}

\author{
Olajide Olubayo THOMAS ${ }^{\star}$, Oloyede Raheem LAWAL ${ }^{\star \star}$
}

\begin{tabular}{l}
\hline \multicolumn{1}{c}{ A R T I C L E I N F O } \\
\hline Article history: \\
Accepted April 2020 \\
Available online August 2020 \\
\hline JEL Classification \\
M10, M11 \\
Keywords: \\
Exploratory Research Design, \\
Management Sciences, \\
Methodological, Phenomenon
\end{tabular}

\section{Introduction}

Every research problem is unique in its own way but almost all research problems and research objectives can be harmonized to one of these three types of research designs- exploratory, descriptive, or causal otherwise known as experimental research. The researcher's choice of design to use when carrying out a research depends on available information. Meanwhile, exploratory research design (ERD) is employed by researchers to gain background information about a phenomenon. ERD is used to clarify research problems and hypotheses and to establish research priorities. Research hypothesis is a statement based on limited evidence which can be proven or disproved and leads to further investigation. It helps organisations to formulate their research problems clearly (Mohajam, 2018).

ERD is conducted for a research problem when the researcher has no past information or only a few studies for references. Sometimes this research is informal and unstructured. It serves as a tool for initial research that provides a hypothetical or theoretical idea of the research problem (Saunders, Lewis \& Thornhill 2007 as cited in Tesfaye, 2018). ERD is flexible and provides the initial ground work for future research. It also requires the researcher to investigate different sources such as published secondary data, data of other surveys, observation of research items, and opinions about a phenomenon. Exploratory researches in management sciences can be defined in different ways, but mainly, researcher believe, it is an attempt to discover something new and generate information.

Therefore, it is working researcher way of developing a research topic. Doing this type of research is risky by definition, since it is not possible to know in advance if something novel will come out of the whole thing. And for an answer, researcher has to wait until researcher is well into the research process (Richard, 2018). The opposite is unfortunately not the case; and all exploratory research, as most of the people known from experience, does not result in something innovative. But again, this can only be found out at a point when researcher is deep into the research. (Brown, 2006; Singh, 2007).

Exploratory research is defined as the soul of good research (Richard, 2018). Without the ambition to find something new, research would come to a standstill. Meanwhile, non-exploratory researches by definition only result in repetition of what is already known. Apart from studies that aim at replication, this will not move science forward (Sauder, Lewis \& Thornhill, 2012). Thus, there exists a problem with defining exploratory research in this way: and this is because it becomes very broad and difficult to handle. The notion that research should be conducted with the ambition to find something new is imperative, but it only carries researcher so far when the term exploratory research is used in this sense. It also has a tendency to become

^, ${ }^{\star \star}$ Lagos State University, Nigeria. E-mail addresses: bayolajide2005@yahoo.com (0. 0. Thomas), soloyederaheem@gmail.com (0. R. Raheem) 
synonymous with all that is regarded as good research- plus everything that has led to this result. This means a very huge, and one that already covers a host of different topics.

This study seeks to provide more insight to exploratory research design in management sciences. inspired by the debates on qualitative methods (Gerring, 2012; George \& Bennett, 2005; Brady \& Collier, 2004; Mahoney \& Rueschemeyer, 2003; Ragin, 2008). The researcher seeks to further demonstrate that exploratory research also has a place in the management sciences. To be reliable, exploratory research should be conducted in a transparent, honest and strongly self-reflexive way and follow a set of guidelines to ensure its reliability. In essence, if ERD is been conducted in this fashion, then the study will achieve great validity and provide new and innovative ways to analyze reality.

\section{Statement of the Problem}

In management sciences today, a research that is been considered to be a good research design is considered as appropriate, efficient and economical, because it minimises bias in data collection (Jamia, 2016). Therefore, ERD emphasis on the main stage of research in order to achieve new insights into a phenomenon. Exploratory studies deserve to be part of the general toolkit of the management sciences.

Some studies have been reviewed on exploratory research in management sciences and probably none contains anything close to a full discussion and presentation of exploratory studies. A few studies on exploratory research (King, Keohane \& Verba 1994; Lewis-Beck, Bryman \& Futing Liao 2004; Somekh \& Lewin 2005; Gray et al 2007; Della Porta \& Keating 2008; Walters 2010; Gerring 2012), were of the opinion that research is intended as a resource and an indispensable companion to welcome researcher into the field of management sciences research. Though, it is recognized that some methodological frameworks are incompatible with others, but the overarching premise of the study is to indicate how a wide range of researchers choose a methodology and methods which are appropriate to both the areas of inquiring and their own way of seeing the world. Scholars are invited to explore the ideas in these studies, seeking to learn with an open mind and revisit the previous challenges.

It is important to note that exploratory research is dominant and prominent in social sciences (Francois, 2008; John, 2015), however, it is gaining some recognition in management sciences (Richard, 2018). Thus, exploratory research is usually useful for researchers when carrying out a study and there are inadequate data or no previous studies to which references can be made. As a result, exploratory research is more appropriate in case of research problem which little research knowledge is available. Scholars in management studies might probably have interest in such a problem and to obtain insights about the little knowledge that is available (Bass, Beecham \& Noll, 2018).

\section{Objective of the Study}

The objective of this study is to examine the appropriate usage of research instrument or tools in management sciences.

\section{Methodology of the Study}

This paper used exploratory research techniques and it relies on secondary data collected from various publications, journals, textbooks, and internet sources.

\section{Literature Review \\ Concept of exploratory research}

Exploratory research helps to determine the best research design, data collection method and selection of subjects. Exploratory research draws definitive conclusions only with extreme caution. Given its fundamental nature, exploratory research often relies on techniques such as (i) quantitative research by reviewing available literature (ii) Informal qualitative approaches like discussions with consumers, employees, management or competitors. (iii) formal qualitative research through in-depth interviews, focus groups, projective methods, case studies or pilot studies (Jamia, 2016).

When research intends to gain understanding about a phenomenon in order to formulate a more precise problem or to develop a hypothesis, exploratory studies (also known as formulative research) come in handy. If the theory happens to be too general or too specific, a hypothesis cannot be formulated. Therefore, a need for an exploratory research may be realized and instituted to gain experience that may help in formulating a relevant hypothesis for more definite investigation (Shieids \& Rangarjan, 2013).

Exploratory research is not typically generalizable to the population at large. Meanwhile, social exploratory research "seek to find out how people get along in the setting under question, what meanings they give to their actions, and what issues concern them. The goal is to learn 'what is going on hesre?' and to investigate social phenomena without explicit expectation (John, 2015).

Mouton (1996) highlights aims of exploratory studies is to include establishing of facts, gathering new data and determining meaningful patterns or themes in a relatively unknown research area, hoping to gain new insight into the phenomenon being researched. Babbie (2007) claims that "exploratory studies ares most typically done for three purposes: (i) to satisfy the researcher's curiosity and desire for better 
understanding, (ii) to test the feasibility of undertaking a more extensive study, and (3) to develop the methods to be employed in any subsequent study'.

Tesfaye (2018) posits two ways that exploratory research can be conducted which are (i) primary and (ii) secondary source. Meanwhile, under these two sources, there are multiple methods that researchers may use for gathering data such as expert surveys, pilot surveys, secondary data, qualitative interviews, unstructured, observations, and quantitative exploratory (Asika, 2004)

Figure 1. A Conceptual Model of Exploratory Research

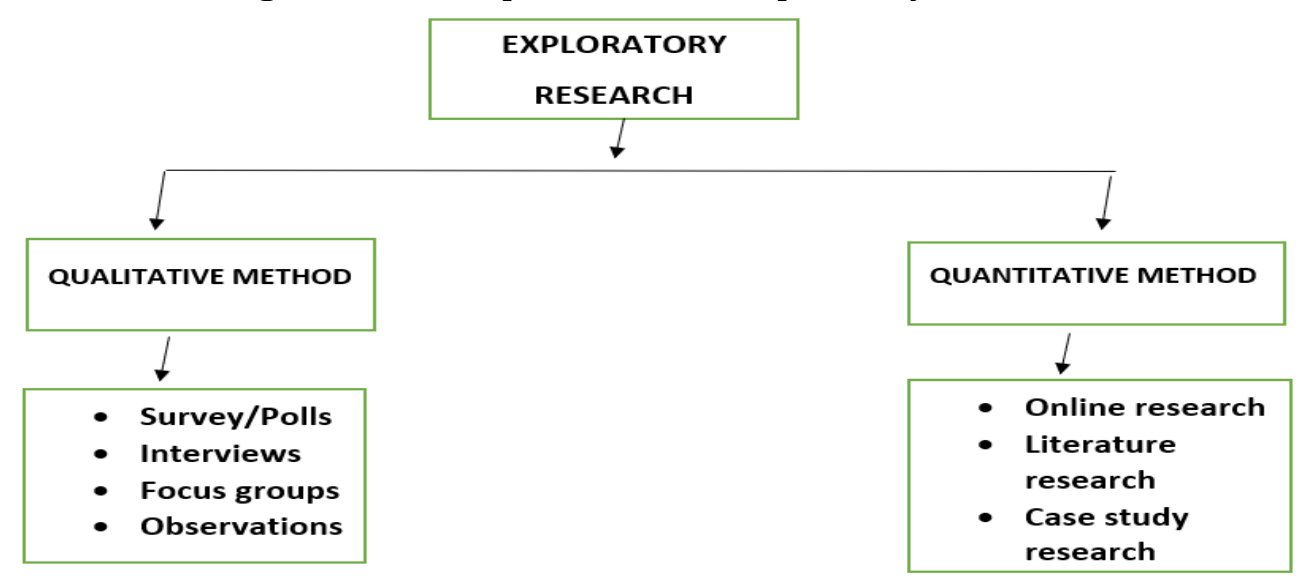

Source: Adapted from Tesfaye (2018).

\section{Qualitative Methods}

Primary research is information gathered directly from the subject. This may be done through a group of people or an individual. Such a research can be carried out directly by the researcher himself or the researcher can employ a third party to conduct it on his behalf. Qualitative research is specifically carried out to explore a certain problem which requires an in-depth interview. As such, under this we have the following survey or poll, interview, focus groups and observation.

\section{Quantitative Methods}

While the secondary research is collection of information from the previous published primary research. In such a research, the researcher can gather information from sources like online, journals, articles, case studies, magazines, newspaper, books, etc.

\section{Steps involved in Conducting Exploratory Research}

There are three steps involved when conducting exploratory study by a researcher which are i. Identify the problem ii. Create the hypothesis iii. Further research (Adi, 2019).

\section{Advantages and Disadvantages of Exploratory Research}

Mohajan (2018) pointed out the following advantages and disadvantages that researcher can benefit from exploratory research design in management sciences and these are listed below. The advantages are

i. Flexibility and adaptability to change.

ii. laying ground work which will lead to further studies.

iii. It is used to develop techniques for measuring and locating future data.

While disadvantages of exploratory research are:

i. It generates qualitative information and interpretation and this type of information is subject to bias.

ii. It usually makes use of a modest number of samples which may not sufficiently represent the target population of the study. Therefore, the results cannot be generalised to a wider population.

iii. And finally, this type of study is not usually useful in decision making in a practical level. 


\section{Catalogue of Qualitative and Quantitative Sources Method Usage for Exploratory Research}

Table 1: Showed the methods that previous researcher(s) used for data collection.

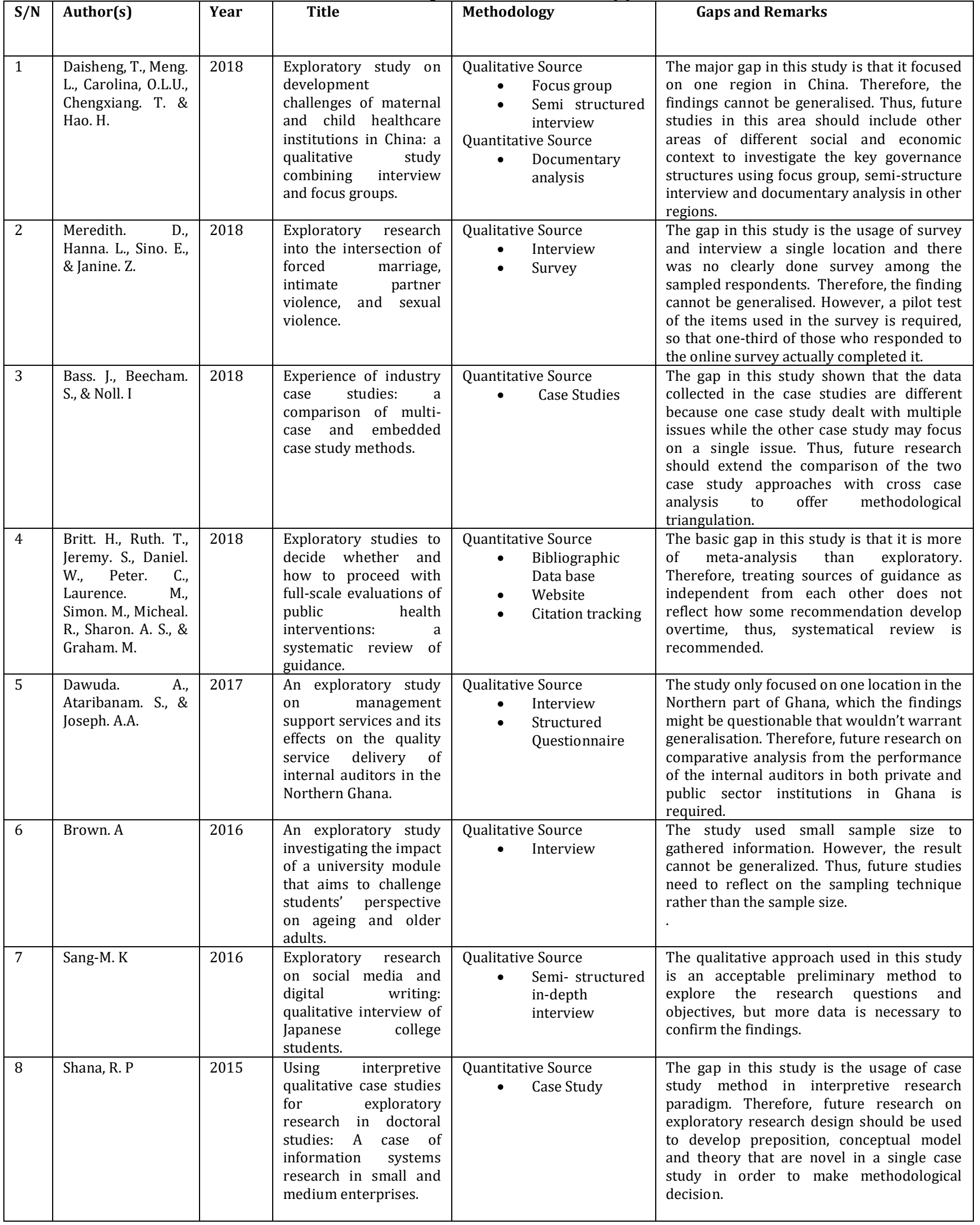




\begin{tabular}{|c|c|c|c|c|c|}
\hline 9 & $\begin{array}{l}\text { Philmore. A., \& } \\
\text { Diana. W. M }\end{array}$ & 2011 & $\begin{array}{l}\text { An exploratory study of } \\
\text { management } \\
\text { accounting practices in } \\
\text { manufacturing } \\
\text { companies in Barbados }\end{array}$ & $\begin{array}{l}\text { Qualitative Source } \\
\qquad \quad \text { Semi- Structure } \\
\text { interview }\end{array}$ & $\begin{array}{l}\text { In this study qualitative approach was used } \\
\text { to collect data which may not allow } \\
\text { confidential and anonymous reporting by } \\
\text { respondents. For researcher to obtain } \\
\text { information on management accounting } \\
\text { practices it is appropriate to use } \\
\text { questionnaire (survey design). }\end{array}$ \\
\hline 10 & $\begin{array}{lll}\text { Carmen. } & \text { B., } \quad \& \\
\text { Daniela. I } & & \end{array}$ & 2011 & $\begin{array}{l}\text { Exploratory research } \\
\text { on the organizational } \\
\text { learning in small } \\
\text { enterprises } \\
\begin{array}{l}\text { implications for the } \\
\text { economic } \\
\text { educayion. }\end{array} \\
\end{array}$ & $\begin{array}{cl}\text { Qualitative Source } \\
\bullet \quad \text { Semi-Structure } \\
\text { interview }\end{array}$ & $\begin{array}{l}\text { The gap in this study is that researcher was } \\
\text { not allow for participation. Therefore, future } \\
\text { research should give more involvement of } \\
\text { researchers to participation in the } \\
\text { investigation in order to give more ample } \\
\text { and authentic results. }\end{array}$ \\
\hline 11 & $\begin{array}{l}\text { Joseph. P., \& Dawn. } \\
\text { G. G }\end{array}$ & 2010 & $\begin{array}{l}\text { An exploratory study of } \\
\text { website information } \\
\text { content }\end{array}$ & $\begin{array}{cc}\text { Quantitative Source } \\
\qquad \quad \begin{array}{l}\text { Literature } \\
\text { review }\end{array}\end{array}$ & $\begin{array}{l}\text { This study only addressed the specific } \\
\text { domains and questions being investigated, } \\
\text { without considering the nature of their } \\
\text { domain such as product or service and the } \\
\text { size of the business. Therefore, research can } \\
\text { evaluate a large number of sites in a given } \\
\text { domain to further investigate how } \\
\text { information context influence user } \\
\text { perceptions and behaviour. } \\
\text {. }\end{array}$ \\
\hline
\end{tabular}

Source: Researcher (2020)

\section{Summary of Findings}

Having reviewed several articles on the subject matter by different researchers using exploratory research design to gather data. It was observed that some scholars were able to collect data through different methods such as primary and secondary sources. The researcher noted that multiple methods were used in a single study for data collection which involves the use of qualitative and/or quantitative sources in order to maximise the strengths and minimise the weaknesses of each method in a research process. Thus, this approach of a multiple method for gathering data helps researchers to answer questions that cannot be answered when using only qualitative or quantitative method alone.

\section{Conclusion}

Exploratory research therefore seeks to generate a posteriori hypothesis by examining a data-set and looking for potential relations between variables. Therefore, it is possible to have an idea about a relation between variables but to lack knowledge of the way and the strength of the relation. If the researcher does not have any specific hypotheses beforehand, meaning that the study is exploratory with respect to the variables in question.

Exploratory research design is easier to make new discoveries due to the less rigorous methodological limits. The researcher may want to see whether some of research measured variables could be related and to increase the chances of finding as a significant result by lowering the beginning of what researcher deem to be significant.

\section{Recommendations}

Based on the conclusion above, this paper recommends for management sciences researchers to adopt multiple methods approach for data collection when conducing exploratory research. Meanwhile, the use of these three approaches for data collection, namely: interview, observation and survey, is to meet the doctrine of exploratory research design and to satisfy the researcher's curiosity as well as the desire for better understanding of a phenomenon.

\section{References}

1. Adi. B. (2019). Exploratory research. Definition, methods, types and examples. Retrieved from https://www.questionpro.com.

2. Azika. N. (2004). Research methodology. A process approach. Lagos, Mukugamu \& Brothers Enterprises.

3. Babbie, E.R. (2007). The Practice of Social Research. Belmont, CA: Thomson Wadsworth.

4. Bass, J, Beecham, S., \& Noll, J. (2018). Experience of industry case studies: a comparison of multicase and embedded case study methods. Retrieved from http://usir.salford.ac.uk/id/eprint/46284/.

5. Britt. H., Ruth. T., Jeremy. S., Daniel. W., Peter. C., Laurence. M., Simon. M., Michael. R., Sharon, A. S., \& Graham. M. (2018). Exploratory studies to decide whether and how to proceed with full-scale evaluations of public health interventions: a systematic review of guidance. Retrieved from http://creativecommons.org/licenses/by/4.0/

6. Brown. A (2016). An exploratory study investigating the impact of a university module that aims to challenge students' perspectives on ageing and older adults. Practitioner Research in Higher Education Journal, 10(2), 25-39.

7. Brown, R. B. (2006). Doing your dissertation in business and management. The reality of research and writing. UK, Sage Publication.

8. Carmen. B., \& Daniela. I. (2011). Exploratory research on the organizational learning in small enterprises and implications for the economic higher education. Academy of Economic Studies, Bucharest, Romania,1(2), 464-481.

9. Daisheng.T., Meng. L., Carolina, O.L.U., Chengxiang. T., \& Hao. H. (2018). Exploratory study on development challenges of maternal and child healthcare institutions in China: a qualitative study combining interviews and focus groups. Retrieved from http://dx.doi.org/10.1136/bmjopen-2018-028789 
10. Dawuda. A., Ataribana. S \& Joseph, A.A. (2017). An exploratory study on management support services and its effects on the quality service delivery of internal auditors in the Northern Ghana. International Journal of Accounting Research, 5(2), 1-4.

11. Della. P., Donatella., \& Micheal. K. (2008). Approaches and methodologies in the social sciences. A Pluralist Perspective. Cambridge University Press.

12. Francois. B. (2008). Approaches and methodologies in social sciences. A pluralist perspective. Retrieved fromhttps://halshs.archivesouvertes.fr/halshs-00348853

13. Gerring. J. (2012). Social Science Methodology. A unified Perspective. $2^{\text {nd }}$ ed. Cambridge UK. Cambridge University Press.

14. Gray, P. S., John, B. W., David, A. K., \& John, R. D. (2007). The Research Imagination. An Introduction to qualitative and Quantitative Methods. New York. Cambridge University Press.

15. Jamia, M. I. (2016). Research design. Research in Social Sciences Interdisciplinary Perspectives. Retrieved from https://www.researchgate.net/publication/308915548

16. John. G. (2015). Social sciences methodology. London, Cambridge University Press.

17. Joseph. P.H., \& Dawn, G. G (2010). An exploratory study of website information content. Journal of Theoretical and Applied Electronic Commerce Research, 5(3), 27-38.

18. King. G, Robert. K., \& Sidney. V. (1994). Designing social inquiry. Scientific inference in qualitative research. USA, Princeton University Press.

19. Lewis. B., Micheal, A. B., \& Tim, F. L. (2004). The Sage Encyclopedia of Social Science Research Methods. London. Sage.

20. Louise. K. (2008). Teenagers' perceptions of advertising in the online social networking environment. Queensland University of technology.

21. Meredith. D., Hanna. L., Sino. E., \& Janine. Z. (2018). Exploratory research into the intersection of forced marriage, intimate partner violence, and sexual violence. This resource is being made publically available through the Office of Justice Programs' National Criminal Justice Reference Service.1-36.

22. Mohajah. H. (2018). Qualitative research methodology in social sciences and related subjects. Journal of Economic Development, Environment and People, 7(1), 23-48.

23. Mouton. J. (1996). Understanding social research. Book Review. Health SA Gesondheld, 1(2), 1-13.

24. Philmore. A. \& Dian, W.M. (2011). An exploratory study of management accounting practices in manufacturing companies in Barb ados. International Journal of Business and Social Science, 2(9),49-58.

25. Richard. S. (2018). On the uses of exploratory research and exploratory studies in social science. Cornel University, department of sociology.

26. Sang, M.K. (2016). Exploratory research on social media and digital writing. Qualitative interview of Japanese college students. Journal of Socio-Informatics, 8(1), 13-27.

27. Saunders. M., Lewis. P., \& Thornhill. A. (2012). Research methods for business students. $6^{\text {th }}$ edition. Pearson Education Limited.

28. Shana, R. P. (2015). Using interpretive qualitative case studies for exploratory research in doctoral studies: a case of information systems research in small and medium enterprises. International Journal of Doctoral Studies, 10(1), 535-550. Retrieved from http://ijds.org/10/IJDSv10p535-550Ponelis0624.pdf

29. Shield. P., \& Rangarajan. N. (2013). A Playbook for Research Methods Integrating Conceptual Framworks and Project Management. New Forum Press.

30. Singh. K. (2007). Quantitative Social Research Methods. Retrieved from https://dx.doi.org/10.4145/978935157741

31. Somekh, B. \& Cathy. L. (2005). Research Methods in the Social Sciences. London. Sage

32. Tesfaye. B. (2018). Chapter five research design and methodology. Retrieved from https:www.researchgate.net/publication/329715052

33. Tesfaye. B. (2019). Chapter 4 research design and methodology. University of Pretoria.

34. Timothy, J. M. (1999). Case studies and the statistical worldview. Review of King, Keohane, and Verba's designing social inquiry: Scientific inference in qualitative research. International Organization 53(1), 161-190.

35. Walters. M. (2010). Social research methods. $2^{\text {nd }}$ ed. Oxford, Oxford University Press. 